\title{
Emotional and academic effects of cyberbullying on students in a rural high school in the Limpopo province, South Africa
}

\begin{tabular}{|c|c|}
\hline \multicolumn{2}{|c|}{$\begin{array}{l}\text { Authors: } \\
\text { Parvaneh Farhangpour }{ }^{1} \text { (D) } \\
\text { Cynthia Maluleke }{ }^{2} \text { (D) } \\
\text { Humbulani N. Mutshaeni }{ }^{1}\end{array}$} \\
\hline \multicolumn{2}{|c|}{$\begin{array}{l}\text { Affiliations: } \\
{ }^{1} \text { Centre for Higher Education } \\
\text { Teaching and Learning, } \\
\text { University of Venda, } \\
\text { Thohoyandou, South Africa }\end{array}$} \\
\hline \multicolumn{2}{|c|}{$\begin{array}{l}{ }^{2} \text { School of Human and Social } \\
\text { Sciences, University of Venda, } \\
\text { Thohoyandou, South Africa }\end{array}$} \\
\hline \multicolumn{2}{|c|}{$\begin{array}{l}\text { Corresponding author: } \\
\text { Humbulani Mutshaeni, } \\
\text { Nancy.mutshaeni@univen. } \\
\text { ac.za }\end{array}$} \\
\hline \multicolumn{2}{|c|}{$\begin{array}{l}\text { Dates: } \\
\text { Received: } 02 \text { Nov. } 2017 \\
\text { Accepted: } 31 \text { Jul. } 2018 \\
\text { Published: } 20 \text { Mar. } 2019\end{array}$} \\
\hline \multicolumn{2}{|c|}{$\begin{array}{l}\text { How to cite this article: } \\
\text { Farhangpour, P., Maluleke, } \\
\text { C. \& Mutshaeni, H.N., 2019, } \\
\text { 'Emotional and academic } \\
\text { effects of cyberbullying on } \\
\text { students in a rural high } \\
\text { school in the Limpopo } \\
\text { province, South Africa', } \\
\text { South African Journal of } \\
\text { Information Management } \\
21(1), \text { a925. https://doi.org/ } \\
\text { 10.4102/sajim.v21i1.925 }\end{array}$} \\
\hline \multicolumn{2}{|c|}{$\begin{array}{l}\text { Copyright: } \\
\text { (C) 2019. The Authors. } \\
\text { Licensee: AOSIS. This work } \\
\text { is licensed under the } \\
\text { Creative Commons } \\
\text { Attribution License. }\end{array}$} \\
\hline \multicolumn{2}{|l|}{ Read online: } \\
\hline 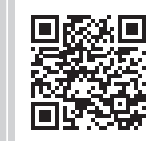 & $\begin{array}{l}\text { Scan this QR } \\
\text { code with your } \\
\text { smart phone or } \\
\text { mobile device } \\
\text { to read online. }\end{array}$ \\
\hline
\end{tabular}

Background: The overwhelming use of Internet and social media among the youth in South Africa causes both negative and positive effects on the users. Cyberbullying is one manifestation of such negative effects. Rural high school students are not immune to this modern age social problem. To protect them against the possible hazards, it is important to study this phenomenon among this group of young poeple.

Objectives: This study explored the extent of the use of Internet and social media, the forms and frequency of cyberbullying and their effects on the emotional well-being and academic performance of grades 8-10 students in a rural high school in Limpopo, South Africa.

Method: This study used a mixed research approach. Eighty participants consisting of 50 females and 30 males from grades 8 to 10 in a rural high school participated in this survey and 6 purposefully selected victims of cyberbullying completed an interview schedule.

Results: The majority of participants had access to cyber technology and used Facebook frequently. More than half of the participants experienced a wide variety of cyberbullying, sexual offence being the highest. They were negatively affected both emotionally and academically to the extent that some thought of suicide.

Conclusion: Even though students in this rural high school have access to the latest cyber technology, they are not equipped to prevent or cope with its negative effects; hence, they suffer in solitude. The study recommends an anti-cyberbullying policy being established, as well as counselling at school, and advises stakeholders who intend to expand e-learning at schools to include cyber safety and supportive mechanisms in their programmes for successful implementation.

\section{Introduction}

It was not long ago that the world was introduced to the Internet and cyber technology, yet these have crept into the lives of people in every corner of the world, surpassing any other form of technology in speed of expansion and popularity. The most common device that makes this technology accessible to ordinary men and women is the mobile phone. According to Statista (2016), in 2014 about $60 \%$ of the world's population already owned a mobile phone and it predicted that in 2017 this number would reach 4.77 billion. In another report, Skiba (2014) estimates that $79 \%$ of young adults aged 18-24 years have smartphones that allow them to connect to the Internet. South Africa ranks 28th in the world, with 80 million active cell phones in comparison to its 52.98 million population, which is equal to 1.5 cell phone SIM cards per individual (News24 2015). The overwhelming penetration of mobile technology and increasing access to cyber space presents the users with many advantages, as well as challenges as its side effect. One of the challenges is the abuse of this technology for bullying. 'Cyberbullying' refers to the intentional act of using any cyber medium such as mobile phones, chat rooms, emails, instant messaging and social networking sites to hurt someone or a group of people (Belsey 2004; Goodno 2011). The growing increase in the use of laptop computers, tablets and smartphones has made cyberbullying a global problem (Campbell 2005). In a study on 18000 people from 24 countries, including Argentina, Australia, Belgium, Brazil, Canada, China, France, Germany, Great Britain, Hungary, India, Indonesia, Italy, Japan, Mexico, Poland, Russia, Saudi Arabia, South Africa, South Korea, Spain, Sweden, Turkey and the USA, 80\% of the participants found cyberbullying a serious problem (Reuters 2012). NoBully.com (2016) reported that over 1.1 million people visited their site in just 1 month in March 2016 to seek help to deal with cyberbullying. The Cyberbullying Research Center (2016) warned that of the over $80 \%$ of teenagers who use a cell 
phone regularly, about $50 \%$ have experienced some form of cyberbullying, while $20 \%$ of them experienced it regularly.

In South Africa, cyberbullying is reported to be as high as $52 \%$ among Grade 8 students of Cape Town (Townsend et al. 2008), 36.3\% of grades 8 and 11 students in Durban (Liang, Flisher \& Lombard 2007), 24.3\% of Grade 9 students in Port Elizabeth (Flisher \& Lombard 2006), 16.49\% among rural high school students in the Eastern Cape (Mlisa et al. 2008) and $11.8 \%$ in rural high schools in Mpumalanga (Taiwo \& Goldstein 2006).

Research has shown that cyberbullying can have extensive negative impacts on the victims and leave them with devastating scars. For example, Gordon (2016) found that teenage victims of cyberbullying experience anxiety, fear, depression, low self-esteem, resulting in feeling overwhelmed, vulnerable, powerless, revengeful, exposed, humiliated, isolated and losing interest in schooling and life. In some extreme cases it has even caused mental problems, social isolation and suicidal thoughts (Deschamps \& McNutt 2016). In view of the severity of the side effects of cyberbullying, its speedy expansion and evolving nature, as well as shortage of studies on cyberbullying in rural schools in the Limpopo province, South Africa, this study was carried out. The study was conducted in a rural high school in a village in the north of the Limpopo province in 2015. The objectives of the study were to investigate: (1) students' access and use of cyber technology, (2) choice of social media sites, (3) forms and frequency of cyberbullying, (4) effect of bullying on emotional well-being and academic performance, and (5) students' views on how to deal with the problem of cyberbullying. With the plan of government and some universities to expand the use of Internet in rural schools, it is important to understand how cyber technology is used by rural students and the possible cyberbullying challenges that they face, to come up with preventative measures to address the concerns of this under-privileged sector of South African society.

\section{Cyberbullying in context}

With the advent of the Internet, the nature and form of socialisation among youth has been transformed. Physical socialisation in the form of attending parties and group gettogethers has been replaced with conversations in chat rooms, textmessages and other forms of cyber communication. Young people go online, using social networking sites to connect to peers, to exchange views, to socialise and feel socially accepted and a part of the group (Farhangpour \& Matendawafa 2014). It is not surprising that the old act of school bullying or 'offline' bullying has been transferred to the cyber platforms. Cyberbullying is a modern form of traditional or offline bullying and similar motives that instigated traditional bullying are now manifested online through text messages or social networking sites. Faucher, Jackson and Cassidy (2014) define cyberbullying as online exchanges with the intention to harm the recipient. Cyberbullying appears in various forms. The National Crime Prevention Council (2011) has provided the following list: sending threatening messages, spreading rumours, attacking someone verbally, intentionally excluding someone from the group, pretending to be someone else, publicising unflattering pictures of a person, circulating sexually suggestive pictures and sharing confidential information online.

Cyberbullying is especially frequent in schools. Taking the example of USA, the number of cyberbullying incidents between 2004 and 2013 seems to have steadily increased. Ybarra and Mitchell's (2004) survey of Internet use among 1501 youths aged 10-17 years in USA showed that $4 \%$ were bullied during the previous year. In a survey of 770 youth between the ages of 11 and 19 in 2005 by National Children's Home (2005), 20\% of respondents said that they had been bullied through electronic devices. In another study, Raskauskas and Stoltz (2007) surveyed 84 students aged 1318 years from two high schools; $49 \%$ reported being victims of cyberbullying over the last school year. Juvonen and Gross (2008) surveyed 1454 students from across the USA; they found that about $72 \%$ of the students had encountered cyberbullying at least once during the previous year. Similarly, an online survey of 1378 youth under the age of 18 by Hinduja and Patchin (2008) showed that over $32 \%$ of boys and over $36 \%$ of girls had been victims of cyberbullying. More recently, Muhlhauser (2013) found that $50 \%$ of students in the USA had experienced cyberbullying, where $61 \%$ were females and 39\% males. The increase in the number of cyberbullying incidents over the years in the USA could be linked to the increased number of hours of online activity (Hinduja \& Patchin 2008; Juvonen \& Gross 2008), a phenomenon that is common in most countries around the world.

\section{Cyberbullying in relation to traditional bullying}

It is argued that students who were victims of traditional bullying or 'offline bullying' in schools are now exposed to similar threats through their mobile phones or computers (Ybarra \& Mitchell 2004). However, cyberbullying differs from traditional bullying in several ways that potentially make it more harmful to the victims. Usually the victims of traditional bullying find relief from the bully once they get home (Slonje \& Smith 2008) away from school where bullying usually takes place. This is not the case with cyberbullying as the attackers can continue to bully $24 \mathrm{~h}$ a day, 7 days a week, using social media or other Internet mediums. In traditional forms of bullying, often the physical removal of the victim from the scene puts a stop to bullying; this does not apply to cyberbullying because cyberbullying does not happen through physical contact but electronic messages. Moreover, the audience witnessing the act of bullying in a traditional setting was usually limited to classmates and students at school, whereas in the case of cyberbullying the audience is not known and can extend beyond the circle of classmates and the school community. The fact that a message can go viral on the Net - 'liked' or 'unliked', commented on and shared by an unlimited number of viewers - passing from 
one group to the other - creates an unknown or 'ghost audience' that makes the act of cyberbullying so much more uncomfortable and even dangerous to the victims. This factor can cause high levels of stress and feelings of embarrassment for the victim, as the victim can't determine the scope of exposure and the type of people who witnessed the case. Another difference is that the bully can stay anonymous, making it difficult to be stopped - especially when the victim is unaware of remedial actions and software applications that can block the perpetrator. Moreover, the act of cyberbullying can become contagious; when one member of group starts to bully, others may follow suit. Being invisible to others, as in the case of cyberbullying, can encourage some viewers to start to bully others, as they feel safe in the virtual space, whereas in an ordinary classroom they would not have gotten involved for fear of being named and shamed. Lack of supervision by adults during cyberbullying is another difference that make cyberbullying more 'doable' for the opportunists.

\section{Effect of cyberbullying on psychological health of the victim}

Bullying can seriously affect the health and well-being of the victims, especially their psychological health. Often, victims feel disconnected from school and communities and experience traumatic stress (Hong et al. 2014). According to Raskauskas and Stoltz (2007), victims of cyberbullying may develop poor general psychosocial conditions. In their research they found that $31 \%$ of victimised students reported being very or extremely upset, $19 \%$ were very or extremely scared and $18 \%$ were very or extremely embarrassed by online harassment. They also found that repeated acts of cyberbullying threatened healthy development of self-esteem and contributed to school failure, dropout and increased psychological symptoms such as depression and anxiety (Raskauskas \& Stoltz 2007). Moreover, victims of repeated bullying are likely to accept and internalise the bullies' treatment of them and feel that they have no control over their lives (Parson 2005). As a result, they may further develop a negative outlook on the world with long-term consequences that go beyond psychological harm into a dysfunctional lifestyle. Sheridan (2012) found that 15\% of adults who were victims of bullying during high school had psychological problems and failed to get decent jobs because they were not psychologically suitable. Wolke and Lereya (2015) added that bullying is a major risk factor for adaptation to adult roles such as forming lasting relationships and integrating into the workplace.

If victims of bullying do not get adequate help to deal with the negative effects, the damage can increase, and in extreme cases victims might feel so desperate that they resort to selfharm or commit suicide (Fisher et al. 2012). In 2007, a survey of 1963 middle-school students in the USA showed that both the bullies and the victims had suicidal thoughts but the victims had more suicidal thoughts than others and were more likely to attempt suicide

\section{Effect of cyberbullying on academic performance}

Learners need to concentrate during lessons to perform at their best in school, but being bullied makes it hard for them to concentrate and pay attention in class. In a study conducted by Hureva (2012), 62\% of learners who were victims of bullying did not pay attention to schoolwork, and 5\% said they were always thinking of the bullies. Hong et al. (2014) confirm that cyberbullied students commonly obtain lower grades and are at risk of poor academic performance. Shariff (2008), Myburgh and Poggenpoel (2009) and Hixon (2009) maintain that bullying often leaves victims with mental anguish and destroys their self-esteem, which leads to a drop in academic performance.

Absenteeism from school is another consequence of being bullied by learners at schools globally (Olweus 1993; Rigby 1997). Smith and Sharp (1994) report that some victims of bullying stay absent from school to avoid being bullied. In a study conducted in South Africa by Myburgh and Poggenpoel (2009), it was confirmed that victims of school bullying hate schooling because of their fear of being bullied.

Furthermore, victims of bullying have few or no friends (Olweus 1993; Rigby 1997). Rigby (1997) found that learners who have not been bullied, do not like to be friends with victims of bullying. Smith and Sharp (1994) also found that some victims of bullying intentionally isolate themselves by choosing subjects that many learners are not interested in to avoid the bully. Isolation causes victims to be sad and this may affect their concentration and ability to learn.

\section{Research methodology}

\section{Research design and approach}

The research design was a case study where the effect of cyberbullying among students in one school was studied. In case studies a contemporary phenomenon is empirically investigated within its natural context using various sources of evidence (Yin 2003). The primary advantage of a case study is that it provides rich and comprehensive information about the phenomenon under study (Maree 2009). It provides a holistic understanding of how different elements within a case interact and affect each other. The study adopted a mixed-method approach. In a mixed-method approach, researchers utilise various methods of collecting and analysing data from quantitative and qualitative research approaches in a single research study (Creswell 2009). A quantitative survey questionnaire and a qualitative interview schedule were utilised in this study.

\section{Sampling process and data collection instrument}

The researched school had four Grade 8 classes, five Grade 9 classes and six Grade 10 classes. The researcher used a lucky draw to select one class from each grade and stratified 
probability sampling to select the study sample from each grade.

The sample represented male and female learners in each of the three grades. Based on the proportion of learners in the chosen grades, 20 Grade 8, 30 Grade 9 and 30 Grade 10 learners were randomly selected. The total sample for the study consisted of 80 learners ( 30 males and 50 females) aged 12-18 years old. The participants completed a cyberbullying survey questionnaire, which consisted of 37 questions. The questionnaire was first piloted among a few students in the same school and was improved accordingly. For the qualitative research, purposeful snowball sampling was used. The first cyberbullying victim was identified by the teacher, who in turn introduced the other five respondents to the researcher, who completed a qualitative interview schedule in writing. There were five female victims and one male victim. The data from the quantitative survey provided answers for research questions on the access, use, popular sites, and frequency and forms of cyberbullying, and the qualitative data provided answers for the nature and effect of cyberbullying on the victims. The quantitative data was analysed using descriptive statistics methods including percentages and frequency and the qualitative data was analysed thematically.

\section{Study location and ethical considerations}

The location of study was a rural high school in Thulamela Municipality in the Limpopo province (see Figure 1). The municipal area is characterised by a tribal lifestyle and high levels of poverty, resulting in low income per household in settlements. In this municipality, females are in the majority
(100 females vs. 82 males) and 54.4\% are heads of households. Approximately $17.4 \%$ of residents do not have any education, over $43.8 \%$ are unemployed and youth unemployment is at $58.3 \%$ (StatsSA 2016). This description points to the fact that the school under study is located in a very poverty-stricken area where most people have low income, the majority of youth are without jobs and there are more females in the community than men.

\section{Ethical consideration}

Ethical procedures were followed and permission from the school principal, the school governing body and written permission from the parents of the participants were obtained. The participants were verbally and in writing informed of their rights before participating in the survey. The principle of confidentiality was fully observed as the questionnaire was anonymous and the qualitative interview schedule was filled in, in private.

\section{Results \\ Access to cyber technology, popular sites and frequency of use}

In total, 67 (84\%) of the participants said that they had a cell phone and had access to the Internet; the rest accessed the Internet through their friends' phones.

The great majority of the study participants (90\%) confirmed that their favourite social media site was Facebook and they used it regularly. Out of the 80 participants, a majority $67(84 \%)$ used social media more than twice a week. Overall, $95 \%$ of participants used the Internet at least once a week.

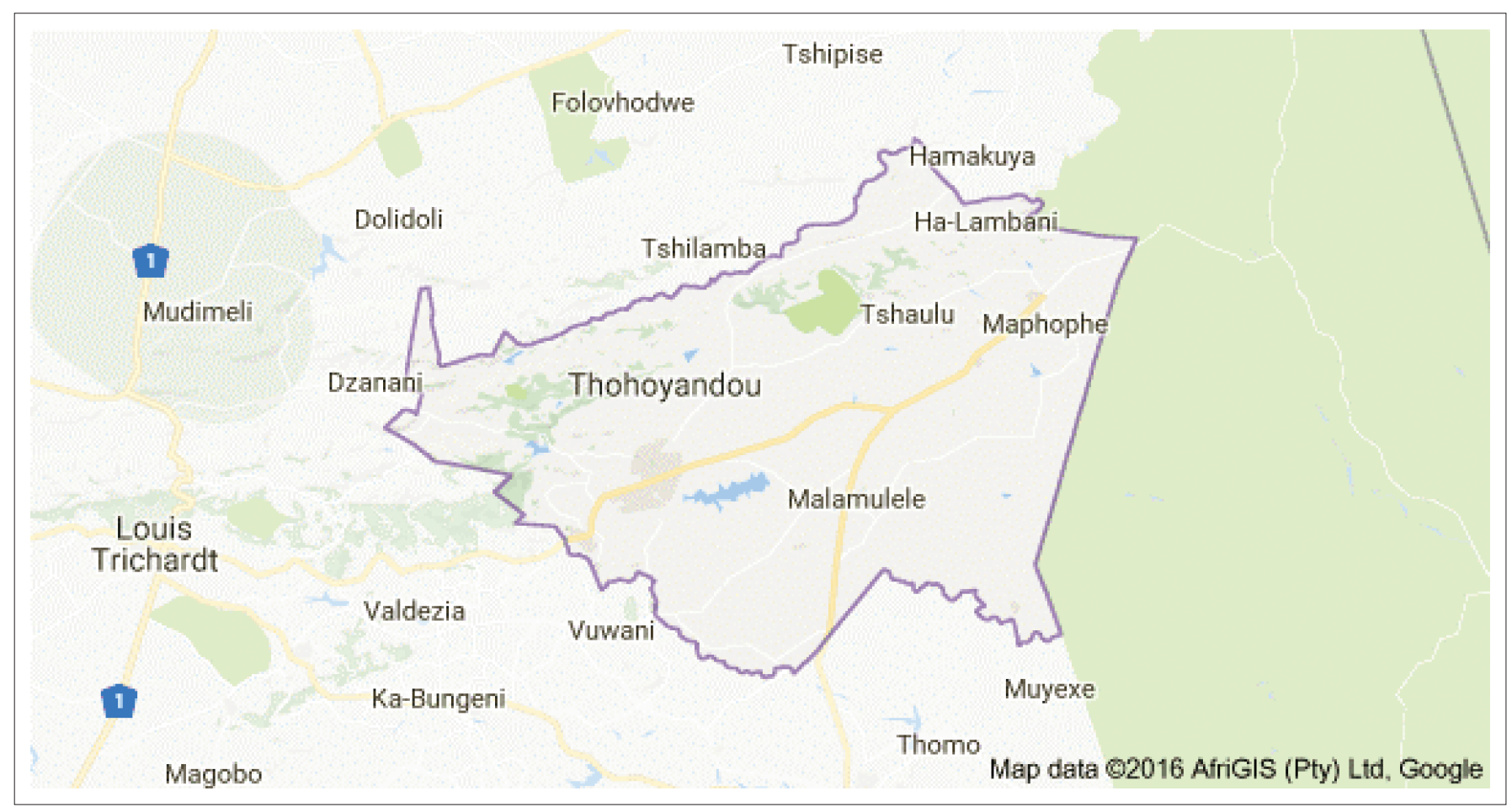

Google Maps, 2016, Thulamela, viewed n.d., from https://goo.gl/maps/Lv2tPUELXYm

FIGURE 1: Map of Thulamela Municipality. 


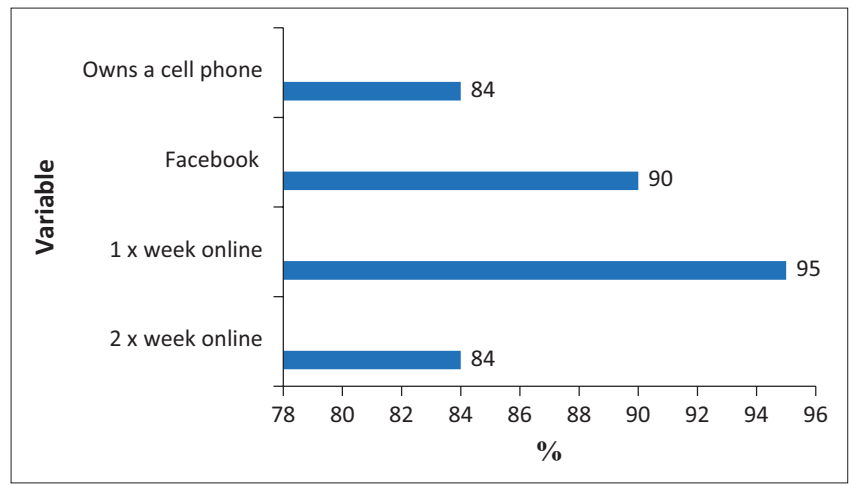

FIGURE 2: Use of social media and cell phones as a percentage $(N=80)$.

\section{Forms of cyberbullying}

The participants of this study experienced different forms of cyberbullying and on a frequent basis, as illustrated in Figure 2. Out of the 80 participants, 54 (68\%) were victims of sexual harassment whereby the bully posted offensive sexual pictures or videos on social media, $53(66 \%)$ experienced rumours being spread about them, 52 (65\%) received aggressive text messages, 49 (61\%) received harmful remarks because of their background, $48(60 \%)$ received pictures of parts of their body, $48(60 \%)$ were called harmful names, 47 (59\%) were teased and 42 (55\%) were deliberately ignored by their peers.

As for the nature of cyberbullying, the six cyberbullied victims who filled in the qualitative interview schedule, described their ordeal in the following words. The victims said:

'My ex-boyfriend took pictures when I was naked in [the] shower and I was not seeing that my ex-boyfriend is taking pictures and he took those pictures and posted it on social network.' (Victim 1, female, student)

'My ex-boyfriend take [took] a video after we agreed that we want to see how we perform when we are having sex and not to see video porn for movies but to see our own video of us, but when we separated he took this video and posted it on social media.' (Victim 2, female, student)

'My ex-boyfriend recorded sex video while we were busy having sex using a hidden cell phone while I was not aware that my exboyfriend is taking video and the next day he started a fight after the fight he posted the sex tape video on social media.' (Victim 3, female, student)

'My ex-girlfriend writes [wrote] wrong information about my sexual life.' (Victim 4, male, student)

'My ex-boyfriend shoot me pictures when in [I was] asleep and naked and posted it on Facebook after we separated.' (Victim 5, female, student)

'My ex-boyfriend posted a picture [of] myself and a baboon and compare it and write that it looks like me on social media.' (Victim 6, female, student)

\section{Frequency of being a victim according to gender}

In this study, $45 \%$ of the sample experienced cyberbullying at least once a week and $19 \%$ of them twice or more than twice a week. Table 1 displays the frequency of experience of being a victim of cyberbullying according to gender.

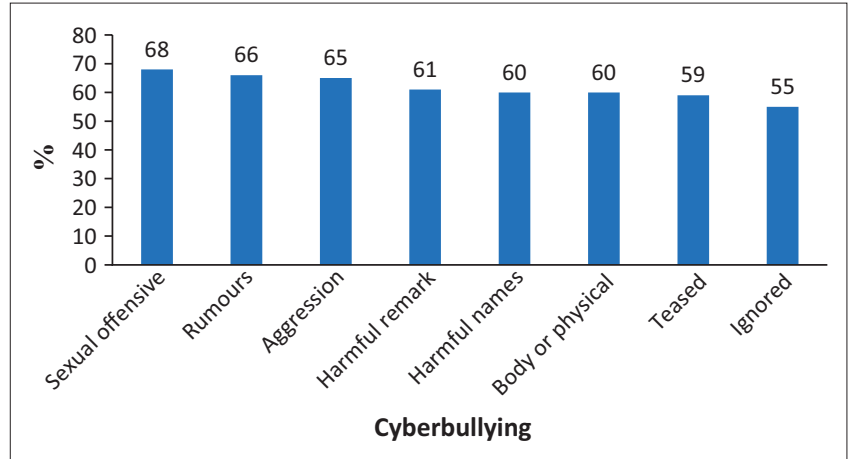

FIGURE 3: Forms of cyberbullying.

TABLE 1: Frequency of being bullied by gender and intervals.

\begin{tabular}{|c|c|c|c|c|c|c|c|c|c|c|c|}
\hline \multirow[t]{2}{*}{ Frequency } & \multirow[t]{2}{*}{$N$} & \multicolumn{2}{|c|}{$\begin{array}{l}\text { More than } \\
2 \times \text { per week }\end{array}$} & \multicolumn{2}{|c|}{$\begin{array}{l}2 \times \text { per } \\
\text { week }\end{array}$} & \multicolumn{2}{|c|}{$\begin{array}{l}1 \times \text { per } \\
\text { week }\end{array}$} & \multicolumn{2}{|c|}{$\begin{array}{l}2 \times \text { per } \\
\text { month }\end{array}$} & \multicolumn{2}{|c|}{$\begin{array}{l}1 \times \text { per } \\
\text { month }\end{array}$} \\
\hline & & $n$ & $\%$ & $n$ & $\%$ & $n$ & $\%$ & $n$ & $\%$ & $n$ & $\%$ \\
\hline Females & 50 & 5 & 10 & 6 & 12 & 24 & 48 & 4 & 8 & 11 & 22 \\
\hline Males & 30 & 2 & 6.6 & 2 & 6.6 & 12 & 40 & 9 & 30 & 5 & 16.6 \\
\hline Total & 80 & 7 & 9 & 8 & 10 & 36 & 45 & 13 & 16 & 16 & 20 \\
\hline
\end{tabular}

Table 1 shows that all participants were subjected to cyberbullying at least once a month. Overall, $70 \%$ of the total participating females experienced cyberbullying at least once a week in comparison to $53.2 \%$ of the male participants. Females were also targeted more frequently than the males (22\% were targeted twice or more than twice a week).

\section{Effects of cyberbullying on emotional well-being}

Cyberbullying affected the emotional well-being of the victims negatively. Out of the 80 study participants, 21\% confirmed that because of cyberbullying they lacked self-confidence, $35 \%$ were depressed, $6 \%$ were frustrated, $15 \%$ were self-conscious, while $23 \%$ had suicidal thoughts.

On the topic of suicidal thoughts, all six interviewed victims experienced suicidal thoughts:

'I thought committing suicide will be the best solution because I won't be ever bullied by any one because I will be dead.' (Victim 1 , female, student)

'I wanted to kill myself because the person who is bullying me keeps on bullying me and people when they see them they laugh at me so that is why I decided that it is better to kill myself.' (Victim 2, female, student)

'I wanted to kill myself because the person who is bullying me on social media was getting worse on bullying me.' (Victim 3, female, student)

'I thought my life was no longer important.' (Victim 4, male, student)

'There is no one around me who is feeling pity and show support but the other learners continue to laugh at me when they see me.' (Victim 5, female, student)

'The community, teachers and everyone around me were not supportive even though they see me that this thing is killing me.' (Victim 6, female, student) 


\section{Effect of cyberbullying on academic performance}

Cyberbullying affected the academic performance of the victims of this study. More than half of the participants (53\%) began to skip school and $11 \%$ completely changed their behaviour, that is, they did not pay attention to schoolwork and joined gang groups so they could be less bullied at school. About $32 \%$ of the victims did not like going to school anymore because of the victimisation, and 34\% thought of quitting school. Being a victim of cyberbullying also affected students' grades. About $41 \%$ of the victims confirmed that they became less active in class, $24 \%$ confirmed that their school performance had dropped and 35\% had repeated a grade since becoming victims of cyberbullying.

Cyberbullying also affected the relationship of the victims with their classmates. Five of the interviewed victims said the effect was negative. For example:

'Some of the learners started to isolate, laugh and reject me after seeing the wrong information that was posted about me on social media.' (Victim 1, female, student)

On the other hand, in the case of Victim 4, the experience was different:

'Many learners gave me support and said that tomorrow it can happen to them.' (Victim 4, male, student)

\section{Measures to deal with cyberbullying}

Participants were asked to offer suggestions on how to deal with the problem. One hundred per cent of the participants suggested that the school should put into place a cyberbullying policy, $92 \%$ believed that there should be consequences for the bullies, $100 \%$ indicated that the teacher should be responsible for dealing with the bullies, 91\% said victims should talk with an adult about bullying in school and $100 \%$ emphasised that the school should prevent bullying.

\section{Discussion}

The study investigated the access and use of cyber technology, choice of social media sites, forms and frequency of cyberbullying, effects of cyberbullying on the emotional well-being and academic performance, and students' views on how to deal with the problem of cyberbullying among 50 female and 30 male students in a rural high school in Limpopo, South Africa, in 2015.

The findings showed that most of the participants (84\%) owned a cell phone and up to $100 \%$ could access the Internet. This figure is comparable to the figures reported by Popovac and Leoschut (2012) that 9 out of 10 (92.9\%) of 12- to 24-yearold youths in Cape Town, Durban and Johannesburg either owned or had access to a mobile phone. This finding is important as it shows that despite the financial constraints dominating this rural community almost all participants managed to access the Internet like their affluent counterparts around the world. They were also aware of cyber technology and made use of it frequently; in this case, a large majority $(84 \%)$ connected to social media sites more than twice a week. This result confirms the findings by Popovac and Leoschut (2012) that accessing social networking sites is youths' favourite online activity in South Africa and Shezi's (2016) findings that 26.8 million South African Internet users spend about $3 \mathrm{~h}$ a day on social media. As for popular social media sites, Facebook was chosen by the majority (90\%) of the participants, which is comparable with the global trends of interest of youth in Facebook (Al-Badi et al. 2013; Cunliffe, Morris \& Prys 2013).

The participants experienced a wide variety of forms of cyberbullying. In total, at least $55 \%$ of the participants experienced all forms of bullying, including sexual offences, rumours, aggressive comments, harmful remarks and name calling, teasing and neglect. These results are very high and compare with findings from a study by Statistic Brain Research Institute (2016) that $52 \%$ of the students were cyberbullied and another study by Fairbairn, Bivens and Dawson (2013) in which $56 \%$ of the youth surveyed had experienced cyberbullying. The most severe form of bullying was sexual offence and remarking on body parts, which was experienced by $68 \%$ of all participants, including males. In this regard, the qualitative questionnaire exposed a shocking picture of what some students had gone through. In four cases a very private and sexual picture or video of a girl was shared on social media by a boyfriend after the break-up, and the male victim complained about his ex-girlfriend posting wrong information about his sexual life. A study by Van Royen, Vandebosch and Poels (2015) showed that cyber sexual harassment is common among adolescents aged $13-18$ years old and ranges from $4 \%$ to $38 \%$. Hoff and Mitchell's (2009) study of the causes of cyberbullying demonstrated that many cyberbullying incidents stem from relationship break-ups, as quoted by the victims in this study.

The high incidence of online sexual offence is very worrisome; and it reflects a nationwide problem in South Africa. A survey by Popovac and Leoschut in 2012 found that 1 in 10 adolescents in South Africa had had embarrassing or damaging pictures taken of them without their permission.

Moreover, cyberbullying incidents were frequent. More than half the participants $(64 \%)$ were cyberbullied at least once a week; a large majority of females (70\%) and more than half of the males (53.2\%) were bullied on a weekly basis. Studies by Hinduja and Patchin (2008), Muhlhauser (2013) and Duggan (2014) showed similar results indicating that more females than males were cyberbullied. The results of cyber victimisation of females in this study further confirms the findings from another study in South Africa (2015 Cyberbullying Data 2016) that adolescent girls were more likely to experience cyberbullying in their lifetimes ( $40.6 \% \mathrm{vs}$. $28.2 \%$ ). This prevalence might be attributed to the dominant discriminative attitude of South African society towards women and the ongoing violence against women. The study 
also found that the cyberbullying victims experienced high levels of emotional stress including depression, frustration and low self-esteem. The most severe impact was depression, experienced by $35 \%$ of the participants. Similar results to this study were found in a study by Patchin and Hinduja (2006) in the USA, where $27 \%$ of victims of cyberbullying reported feeling depressed, which is lower than the results in this study.

The most problematic effect, however, was suicidal thoughts, experienced by $23 \%$ of the sample. This result is very significant, as it shows that close to a quarter of the participants' contemplated suicide even though they did not act on it. This finding indicates that, as Fisher et al. (2012) found, the victims might feel so desperate that they resort to self-harm or commit suicide as reflected in the statement by one of the cyberbullied victims:

'I thought committing suicide will be the best solution because I won't be ever bullied by any one because I will be dead.' (Victim 1, female, student)

A study on 1963 students in the USA in 2007 showed similar results; those who experienced cyberbullying had more suicidal thoughts (Hinduja \& Patchin 2010). This result points to the seriousness of cyberbullying and the victims' levels of desperation, feelings of powerlessness and suffering in isolation. Such feelings warrant immediate support from home and the school.

Cyberbullying also affected the academic performance of the victims in this study, as more than half of the participants began to skip school and about a third of them thought of quitting school. This finding confirms the statement by Townsend et al. (2008) that bullying is one factor that contributes to high rates of absenteeism and consequently school dropouts in South Africa. In another study conducted by Myburgh and Poggenpoel (2009) in South Africa, victims of school bullying hated schooling because of their fear of being bullied, and in another study Madeleine (2011) showed that $54 \%$ of school dropouts were victims of bullying. Being a victim of cyberbullying also affected students' grades. In this study about a quarter of the victims dropped in marks and more than one-third of them repeated a grade. Moreover, cyberbullying negatively affected the relationship of the victim with classmates; one of the victims said:

'Some of the learners started to isolate, laugh and reject me after seeing the wrong information that was posted about me on social media.' (Victim 1, female, student)

Unfortunately, many of the victims felt helpless in the face of cyberbullying when they did not receive support from the very people who were supposed to help them. We heard victims saying:

'There is no one around me who is feeling pity and show support.' (Victim 5, female, student)

'The community, teachers and everyone around me were not supportive even though they see that this thing is killing me.' (Victim 6, female, student)
This void was further highlighted by participants, who in response to the question, 'Suggest measures to deal with cyberbullying', unanimously stated a need for establishing of an anti-cyberbullying policy in the school and the appointment of a counselling teacher, an indicator that they did not receive sufficient support at school. Additionally, students did not refer to software programs that are designed to block cyber perpetrators.

\section{Limitations of the study}

This research was limited to the study of victims of cyberbullying and did not include the bullies. The other limitation was that the frequency of cyber sexual harassment was not measured according to gender. Moreover, the language of the survey questionnaire was English. The participants in this study were not English first-language speakers and even though the teacher assisted in translation of some of the questions in the questionnaires, it is possible that some of the younger respondents did not understand all questions fully as required.

\section{Conclusion and recommendations}

The findings of the study clarified the significance of cyberbullying in the lives of students in this rural high school, which might be experienced by students in similar settings in South Africa. It showed that even though students in this school had access to the latest cyber technology, they were not equipped to prevent and cope with its negative effects and suffered in solitude. The findings are alarming. This study, therefore, recommends the appointment of a counselling teacher and the establishing of an anti-cyberbullying policy at schools. Adoption of such a policy, however, is not without complications and legal considerations (Smit 2015). The success of such a policy depends on continuous consultation and cooperation between parents, teachers, learners and other stakeholders (Hinduja \& Patchin 2008). In view of the fact that government and some universities intend to expand e-learning and cyber technology in all schools in South Africa, including the rural schools, we further urge the inclusion of cyber safety and cyber protection strategies in all e-learning training and the school curriculum. Without preventative measures to address the cyberbullying problem, cyber technology meant to assist students might harm them. Further research on the cyberbullies, as well as studies on gender and sexual cyberbullying, is also recommended.

\section{Acknowledgements Competing interests}

The authors declare that they had no financial or personal relationships that may have inappropriately influenced them in writing this article.

\section{Authors' contribution}

P.F. was the project leader. C.M. was responsible for implementation and data collection. P.F. and H.N.M. were involved in the final write-up of the research report. 


\section{References}

Al-Badi, A.H., Al-Hinai, Y.S., Sharma, S.K. \& Williams, S.H., 2013, 'Usage of social networking tools in research and collaboration', Journal of Emerging Trends in Economics and Management Sciences 4(6), 515-523.

Belsey, B., 2004, Cyberbullying.ca, viewed 27 July 2016, from http://www.cyber bullying.ca/

Campbell, M.A., 2005, 'Cyber bullying: An old problem in a new guise?', Journal of Psychologists and Counsellors in Schools 15(1), 68-76.

2015 Cyberbullying Data, 2016, viewed 25 August 2017, from http://cyberbullying. org/2015-data.

Creswell, J.W., 2009, Research design: Qualitative, quantitative, and mixed methods approaches, 3rd edn., Sage, Thousand Oaks, CA.

Cunliffe, D., Morris, D. \& Prys, C., 2013, 'Young Bilinguals' language behaviour in social networking sites: The use of Welsh on Facebook', Journal of Computer-Mediated Communication 18, 339-361. https://doi.org/10.1111/jcc4.12010

Deschamps, R. \& Mcnutt, K., 2016, 'Cyber bullying: What's the problem?', Canadian Public Administration / Administration Publique du Canada 59(1), 45-71, viewed 20 June 2017, from https://doi.org/10.1111/capa.12159

Duggan, M., 2014, 'Online harassment', Internet, Science \& Tech, viewed 28 June 2016, from http://www.pewinternet.org/2014/10/22/online-harassment/

Fairbairn, J., Bivens, J. \& Dawson, M., 2013, Sexual violence and social media: Building a framework for prevention. Research Gate, Crime Prevention, Ottawa.

Farhangpour, P. \& Matendawafa, A.W., 2014, 'The impact of social network sites on the social health of students', African Journal for Physical, Health Education, Recreation \& Dance Supplement 1,2 .

Faucher, C., Jackson, M. \& Cassidy, W., 2014, 'Cyber bullying among university students: Gendered experiences, impacts and perspectives', Education Research International 2014, Article ID 698545, 10 p. https://doi.org/10.1155/2014/698545

Fisher, H.L., Moffitt, T.E., Houts, R.M., Belsky, D.W., Arseneault, L. \& Caspi, A., 2012 'Bullying victimisation and risk of self-harm in early adolescence: Longitudinal cohort study', BMJ 344, e2683. https://doi.org/10.1136/bmj.e2683

Flisher, J. \& Lombard, C., 2006, 'The relationship between bullying behavior and high school dropout', South African Journal of Psychology 2(33), 21-32.

Goodno, N.H., 2011, 'How public schools can constitutionally halt cyberbullying: A model cyberbullying policy that considers first amendment, due process, and fourth amendment challenges', The Wake Forest Law Review 46, 641-700, viewed 11 May 2016, from http://wakeforestlawreview.com/wpcontent/uploads/2014/ 11 May 2016, from http://wakefo
10/Goodno_LawReview_11.11

Google Maps, 2016, Thulamela, viewed n.d., from https://goo.gl/maps/Lv2tPUELXYm

Gordon, S., 2016, What are the effects of cyber bullying?, viewed 02 September 2017 from http://www.verywell.com/waht-are-the-effects-of-cyberbullying-460558

Hinduja, S. \& Patchin, J., 2008, 'Cyberbullying: An exploratory analysis of factors related to offending and victimization', Deviant Behavior 29, 129-156. https://doi. org/10.1080/01639620701457816

Hinduja, S. \& Patchin, J., 2010, 'Bullying, cyberbullying, and suicide', Journal Archives of Suicide Research 14(3), 206-221. https://doi.org/10.1080/13811118.2010. 494133

Hixon, S., 2009, 'Psychosocial processes associated with bullying and victimization' The Humanistic Psychologist 37(3), 257-270. https://doi.org/10.1080/0887326 0903113519

Hoff, D.L. \& Mitchell, S.N., 2009, 'Cyberbullying: Causes, effects, and remedies', Journal of Educational Administration 47(5), 652-665. https://doi.org/10.1108/ 09578230910981107

Hong, J.S., Davis, J.P., Sterzing, P.R., Yoon, J., Choi, S. \& Smith, D.C., 2014, 'A conceptual framework for understanding the association between school bullyin victimization and substance misuse', American Journal of Orthopsychiatry 84(6), 696-710. https://doi.org/10.1037/ort0000036

Hureva, T., 2012, 'School bullies and education in Botswana', Impact on other Students and Academic Performance 2, 16-27.

Juvonen, J. \& Gross, E.F., 2008, 'Extending the school grounds? - Bullying experiences in cyberspace', Journal of School Health 78, 496-505. Wiley Online Library.

Liang, H., Flisher, A.J. \& Lombard, C.J., 2007, 'Bullying, violence, and risk behavior in South African school students', Child Abuse \& Neglect 31(2), 161-171. https://doi. org/10.1016/j.chiabu.2006.08.007

Madeleine, V.Z., 2011, School bullying in South Africa, Government Press, Pretoria.

Maree, K., 2009, First steps in research, Van Schaik Publishers, Pretoria.

Mlisa, L.M., Ward, C.L., Flisher, A.J. \& Lombard, C., 2008, 'Bullying at rural high schools in the Eastern Cape Province, South Africa: Prevalence and risk and protective factors at school and in the family', Journal of Psychology in Africa 18(2), 261-268. https://doi.org/10.1080/14330237.2008.10820195

Muhlhauser, L., 2013, Copy of cyber bully project, viewed 07 March 2016, from http:// prezi.com/m/idq6udxbcvyp/copy-of-cyberbully-project
Myburgh, C. \& Poggenpoel, M., 2009, 'Meta-synthesis on learners' experience of aggression in secondary schools in South Africa', South African Journal of Education 29(4), 445-460.

National Children's Home, 2005, Putting $U$ in the Picture: Mobile Bullying Survey, viewed 04 September 2005, from http://www.nch.org.uk/uploads/documents/ Mobilebullying\%20report.pdf

National Crime Prevention Council, 2011, Cyber bully statistics, viewed n.d., from http://www.bullyingstatistics.org/content/cyber-bully-statistics.html

News24.com, Cellphone usage in South Africa, viewed 03 November 2015, from http://www.news24.com/MyNews24/Cellphone-usage-in-South-Africa20151103

NoBullying.com, viewed 19 October 2016, from https://nobullying.com/cyberbullying-statistics-2014/

Olweus, D., 1993, Bullying at school: What we know and what we can do, Blackwell, Oxford.

Parson, L., 2005, Bullied teacher, bullied student: How to recognise bullying in school and what to do, Pembroke, Canada.

Patchin, J.W. \& Hinduja, S., 2006, 'Bullies move beyond the schoolyard: A preliminary look at cyber bullying', Youth Violence and Juvenile Justice 4(2), 148-169. https:// doi.org/10.1177/1541204006286288

Popovac, M. \& Leoschut, L., 2012, Cyberbullying in South Africa: Impact and response, Centre for Justice and Crime Prevention, Claremont, pp. 1-16.

Raskauskas, J. \& Stoltz, A.D., 2007, 'Involvement in traditional and electronic bullying among adolescents', Developmental Psychology 43, 564-575. https://doi.org/ 10.1037/0012-1649.43.3.564

Reuters, 2012, Cyberbullying a problem around the globe: Poll, viewed 30 June 2014 from http://www.reuters.com/article/2012/01/11/us-cyberbullying-poll-idUSTRE 80 A1FX20120111

Rigby, K., 1997, Bullying in schools, and what to do about it, Jessica Kingsley, London.

Shariff, S., 2008, Cyber-Bullying: Issues and solutions for the school, the classroom and the home, viewed n.d., from https://books.google.co.za/books/about/Cyber Bullying.html?id=2wYlg0O2rSUC\&redir_esc =y

Sheridan, W., 2012, Kids and teens, viewed n.d., from http://www.erzinearticle.com

Shezi, L., 2016, SA's 26.8 million internet users spend almost three hours a day on social media, viewed n.d., from http://www.htxt.co.za/2016/04/29/the-stuffsouth-africa-26-8-mil-internet-users-spend-most-their-time-doing-online/.

Skiba, D.J., 2014, 'The connected age: Mobile apps and consumer engagement', Nursing Education Perspectives 35(3), 199-201. https://doi.org/10.5480/15365026-35.3.199

Slonje, R. \& Smith, P., 2008, 'Personality and social sciences Cyberbullying: Another main type of bullying?', Scandinavian Journal of Psychology Associations 49, 147-154. https://doi.org/10.1111/j.1467-9450.2007.00611.x

Smit, D.M., 2015, 'Cyberbullying in South African and American schools: A legal comparative study South', African Journal of Education 35(2), Art. \# 1076, 11 p., viewed n.d., from http://www.sajournalofeducation.co.za/index.php/saje/article/ viewed $n . d .$, from
viewFile/1076/542

Smith, P.K. \& Sharp, S. (eds.), 1994, School bullying: Insights and perspectives, Routledge, London.

Statistic Brain Research Institute., 2016, viewed 30 October 2016, from http://www. statisticbrain.com/cyber-bullying-statistics/

StatsSA, 2016, 'Thulamela', viewed n.d., from http://www.statssa.gov.za/?page id=993\&id=thulamela-municipality

Statista., 2016, 'Number of mobile phone users worldwide from 2015 to 2020 (in billions)', viewed n.d., from https://www.statista.com/statistics/274774/ forecast-of-mobile-phone-users-worldwide/

Taiwo, T. \& Goldstein, S., 2006, 'Drug use and its association with deviant behavior among rural adolescent students in South Africa', East African Medical Journal 83(9), 500-506.

The Cyberbullying Research Center, 2016, Cyber Bullying Statistics, viewed n.d., from http://www.bullyingstatistics.org/content/cyber-bullying-statistics.html

Townsend, L., Flisher, A.J., Chikobvu, P., Lombard, C. \& King, G., 2008, 'The relationship between bullying behaviors and high school dropout in Cape Town, South Africa', South African Journal of Psychology 38(1), 21-32. https://doi. South African Journal of Psyc

Van Royen, K., Vandebosch, H. \& Poels, K., 2015, 'Severe sexual harassment on social networking sites: Belgian adolescents views', Journal of Children and Media 9(4), 472-491. https://doi.org/10.1080/17482798.2015.1089301

Wolke, D. \& Lereya, S.T., 2015, Long-term effects of bullying. Archives of disease in childhood, viewed n.d., from https://adc.bmj.com/content/100/9/879

Ybarra, M.L. \& Mitchell, K.J., 2004, 'Online aggressor/targets, aggressors, and targets: A comparison of associated youth characteristics', Journal of Child Psychology and Psychiatry 45, 1308-1316. https://doi.org/10.1111/j.1469-7610.2004.00328.x

Yin, R.K., 2003, Case study research: Design and methods, Sage, Newbury Park, CA. 